\title{
CARCINOGENICITY OF INHALED PLUTONIUM-238 IN THE RAT
}

Charles L. Sanders, Jr., Ph.D.

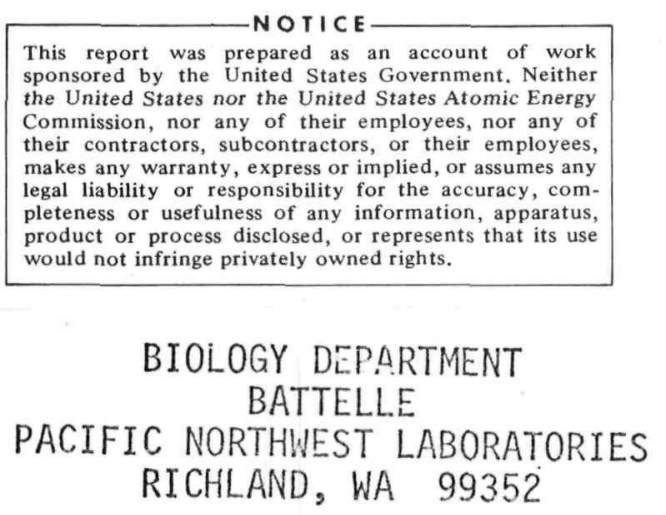

Number of Copies 3

Mânuscript Pages 26

Figures 11

Túbles 3 


\section{DISCLAIMER}

This report was prepared as an account of work sponsored by an agency of the United States Government. Neither the United States Government nor any agency Thereof, nor any of their employees, makes any warranty, express or implied, or assumes any legal liability or responsibility for the accuracy, completeness, or usefulness of any information, apparatus, product, or process disclosed, or represents that its use would not infringe privately owned rights. Reference herein to any specific commercial product, process, or service by trade name, trademark, manufacturer, or otherwise does not necessarily constitute or imply its endorsement, recommendation, or favoring by the United States Government or any agency thereof. The views and opinions of authors expressed herein do not necessarily state or reflect those of the United States Government or any agency thereof. 


\section{DISCLAIMER}

Portions of this document may be illegible in electronic image products. Images are produced from the best available original document. 
CARCINOGENICITY OF ${ }^{238} \mathrm{Pu}$

Charles L. Sanders, Jr., Ph.D.

Biology Department Battelle

Pacific Northwest Laboratories

Richland, WA 9935 ? 
CARCINOGENICITY OF INHALED PLUTONIUM-238 IN THE RAT**

Charles L. Sanders, Jr., Ph.D.

ABSTRACT

Three groups of albino, female rats were exposed to an aerosol of "soluble" ${ }^{238} \mathrm{Pu}$ derived from crushed ${ }^{238} \mathrm{PuO}_{2}$ microspheres suspended in physiological saline. initial alveolar burdens of ${ }^{238}$ Pu were $5 \mathrm{nCi}$ (Group I), 18 nCi (Group II), and $230 \mathrm{nCi}$ (Group III). Only $1 \%$ of the initial alveolar lung burden remained in the lurig at one year, decreasing to $0.3 \%$ by 600 days after exposure. The ${ }^{238} \mathrm{Pu}$ body burden was $25 \%$ of initial alveolar burden at one year, decreasing to $12 \%$ by 1,000 days after exposure; about half of the body burden was found in the skeleton at these times. The cumulative radiation doses to the lung at two years after exposure were 9 rads (I), 32 rads (II), and 375 rads (III). Hhenposed controis exhibited a masiun jurviva? iime of 825 days as compared to experimental survivai times of 650 ciuss (I), 675 days (II), and 550 days (III). The incidence of lung tumors in controls was $1.1 \%$ as compared to incidences in ${ }^{238} \mathrm{Pu}$ exposed rats of $6.6 \%$ (I;, $23.3 \%$ (II), and $25.0 \%$ (III).

The incidence of all tumors, other than mammary tumors, was $4.3 \%$ in unexposed controls, and in ${ }^{238} \mathrm{Pu}$ exposed rats, $26.7 \%$ (I), 36.6\% (II), and $46.8 \%$ (III). It was concluded that exposure of rats to smali amounts of inhaled ${ }^{238} \mathrm{P}_{11}$ resulted in a significant incidence of turors in the iung and otrer tissues.

*This paper is based on research performed under the United States Atomic Energy Commission Cuntract AT(45-1)-1830. 


\section{INTRODUCTION}

Several lifespan studies have been performed with plutonium-239 deposited in the lungs of rodents and dogs, clearly demonsirating the carcinogenicity of piutonium in the lung at rather high radiation doses $(1-7)$. The minimum radiation dose to lungs of animals developing lung tumors after ${ }^{239} \mathrm{Fu}$ exposure is about 50 rads delivered to rats following inhalation of soluble ${ }^{239} \mathrm{Pu}$ compounds $(3)$.

Lung tumors in dogs following inhaiation of ${ }^{239} \mathrm{PuO}_{2}$ particles have been produced only in animals accumulating from 2000 to 20,000 rads to the ling ${ }^{(4)}$. Particulate plutonium deposited in the lung results in foci of intense alpha activity. The number of cells irradiated by such "hot spots" dispersed throughout the lung is considerably less than if the same activity had been more evenly distributed in the lung. Physiological translocation of paiticulate plutonium into subpleural areas may also greatly modify the dose distribution (8). A few relatively large particles of plutonium can arrount for a very large share of the radiation dose delivered to the lung (9).

of the many radioisotopes tested as power sources for space, terrestriai, aquatic oi medical applications, ${ }^{238} \mathrm{Pu}$ is one of the most useful for thermo. eiectric gereration. Plitonium-238 exhitits a specific activity that is 280 times that of ${ }^{239} \mathrm{Pu}$ or a physical half-life of 86 years as compared to 24,000 years for ${ }^{239} \mathrm{Pu}$. Although acute toxicity studies have been performed $(10-12)$ no study has been reported on the corcirogenic responses of animals to inhaled ${ }^{238} \mathrm{Pu}$. This report describes the carcinogenic effects in rats of relatively "low" levels of inhaled ${ }^{238} \mathrm{Pu}$ deposited as a predominantiy monomeric form. 


\section{METHODS}

In June, $i 9 \overline{5} 6,0.25 \mathrm{gram}$ of ${ }^{238} \mathrm{Pu}$ dioxide microspheres were delivered to Battelle-Northwest from the Mound Laboratory in Ohio. The microspheres prepared in a plasma torch, contained about $80 \%{ }^{238} \mathrm{Pu}$ by weight and consisted of spherical particles with diameters ranging from $70 \mu \mathrm{m}$ to $200 \mu \mathrm{m}$, many angular fragments of less than 20-50 $\mu \mathrm{m}$ and numerous smaller particles attached to the surfaces of larger particies. The stock suspension of ${ }^{238}$ Pu was prepared in November, 1969, and animals exposed in January, 1970. The microsphere preparation was lightly crushed in $40 \mathrm{ml}$ distilled water with a porcelain mortar and pestle and then washed io times with $20 \mathrm{ml}$ volumes of water, with one minute intervals between washings for settling out of larger fragments. Twenty $\mathrm{ml}$ of the upper supernatant was discarded following each washing. The lightly crushed microspheres were thoroughty crushed in $40 \mathrm{ml}$ distilled water with mortar and pestle for 10 minutes. The microsphere fragments were very fragile, easily disintegrating with little pressure on the pestle. The resuiting sispension was allowed to settle for several hours. The upper $20 \mathrm{ml}$ containing about $400 \mu \mathrm{Ci}{ }^{238} \mathrm{Pu} / \mathrm{ml}$ was removed by syringe and used for our studiec following appropriate dilution in physiological saline, in which it was stored for 2-3 months prior to its aerosolization.

Distinct, well defined particles with clear borders were rare wheis the ${ }^{238}$ Pu-saline aeroso? was examined with the electron microscope. The aggregates of ${ }^{238} \mathrm{Pu}$ lacked the homogeniety and electron density common to ${ }^{239} \mathrm{PuO}_{2}$ particies ${ }^{(13)}$ (Figure 1). The couni median diameter of the aggregates was approximately $0.02 \mu \mathrm{m}$ with a standard geometric deviation of 2.1 . About $72 \%$ of the ${ }^{238} \mathrm{pu}$ was ultrafilterable ${ }^{(14)}$. Based on this physical characterization, it is probable that the initial ${ }^{238} \mathrm{PuO}_{2}$ was solubitized in the saline in 
which it was suspended $(15-16)$.

Female, 65-80 day 01d, Sprague Dawley, Charles River CD rats were used in this study, following a three week isolation period after being received from the supplier. Thirty-two rais received an intratracheal instillation of $0.7 \mu \mathrm{Ci}{ }^{238} \mathrm{Pu}$ in $0.3 \mathrm{ml}$ physiological saline. Four of these rais were placed in individuai metabo?ism cages for 24 days and their daily excreta collected. The remaining animals were killeú at intervals of one hour to 39 days after instillation.

Three groups of 35 animals each were exposed, nose only, to an aerusol of ${ }^{238} \mathrm{Pu}$ in saline. The exposure equipment and procedures have been previously described ${ }^{(13)}$. Exposure times varied from 10 to 30 minutes. Four arimals were killed each from Groups I and II and 3 animals from Group III at 24 hours after inhalation exposure. The remaining rats were autopsied when moribund or as soon as possible after death. Thirty of 31 lifespan rats in Group I, 3n of 31 in Groun II and 32 of 32 rats in Group III 1 ived longer that 200 days after the exposure; the lifespan analyses are based on these animals. Unexposcd, untreated control animals, living longer than 250 days after birth, corsisted of 92 rats.

At aucopsy, rats were exaillined grossiy for tumor-like growths. The iung, heart, thymus, pulmonary Iymph nodes, liver, spleen, adrenal, kianey, ovary, femur, uterus and other tissues with tumor-like growths were fixed in 10\% neutral suffered formalin and parafín sections prepared for ?ighit microscopic examination following nematoxylin and eosin staining. The amount of ${ }^{238} \mathrm{Pu}$ present in the lung, liver, total skcleton, extra-pulmonary thoracic tissues, gastro-intestival iract. spleen, kidney, skin and that remaining in 
all other tissues, along with the excreta collected from rats given ${ }^{238} \mathrm{Pu}$ by intratracheal instillation, were analyzed for ${ }^{238} \mathrm{Pu}$ contents by liquid scintillation counting following ashing and dissolving in $\mathrm{HNO}_{3}-\mathrm{HF}^{(18)}$. Autoradiographs were prepared of iung and other selected tissue sections. Tumor incidences were expressed as number animals with tumors/number of rats $x$ 100. Animals with more than one tumor of a particular type were considered statistically to have only one tumor of that iype.

\section{RESULTS}

Fate of Intratracheally Instilled ${ }^{238} \mathrm{Pu}$

Excretion - Within 24 hours, $45 \%$ of the intratracheally instilled ${ }^{238} \mathrm{Pu}$ had been excreted in the urine. After 4 days, less than $0.1 \%$ of the instilled dose was excreted daily in the urine. Only about $1.5 \%$ of the instilled dose was found in the feces the first day, decreasing to $U .1 \%$ or less per day by the seventh day after instillation (Figure 2). By 24 days, a total of $49 \%$ and $4 \%$ of the intratracher $17 y$ instilled ${ }^{238} \mathrm{Pu}$ had accumulated in the urine and feces, respectively.

Tissue Distribution - Intratracheally instilled ${ }^{238}$ pu was rapidly cleared from the iurg tc the blood and other tissues. The lung contained about $30 \%$ of instilled ${ }^{238} \mathrm{Pu}$ at 24 inurs, $20 \%$ at 4 ciays, $15 \%$ at 30 days and $12 \%$ at 39 days after its deposition. Transiocation of ${ }^{238} \mathrm{Pu}$ to blood was greatest during the first few hours after deposition, decreasing from $0.2-0.7 \%$ of instilled dosa $/ \mathrm{ml}$ blocut at 1-6 hours to less thân $0.01 \% / \mathrm{m}$ ? after 30 roys (Figure $\hat{\jmath}$ ). The amount of ${ }^{238} \mathrm{Pu}$ translocated to liver rose from $0.2 \%$ of instilled dose at 1-2 hours, to $2 \%$ by 6 hours, to $3 \%$ by the tenth day and then fell to about $1 \%$ of instilied dose by the 39 th day (Figure 3 ). A slower accumulation of 
${ }^{238} \mathrm{Pu}$ into the skeleton was seen. The skeletal burden was $5 \%$ of instilled dose at 2 hours, about 10\% at 24 hours, leveling off to about $20 \%$ of instilled dose thereafter (Figure 3). The body burden of ${ }^{238} \mathrm{Pu}$ decreased by $10 \%$ the first 6 hours, by $50 \%$ the first day and by $55 \%$ by the 39 th day after instillation (Figure 3).

Fate of Inhaied ${ }^{238} \mathrm{Pu}$

Determination of Initial Alveolar Deposition - From 3-4 rats in each exposure group were killed at 24 hours after inhalation of ${ }^{238} \mathrm{Pu}$. The mean amount of ${ }^{238} \mathrm{Pu}$ measured in the lungs of autopsied animais of each group at 24 hours postexposure were $1.6 \pm 1.3$ for Group I, $5.9 \pm 3.2$ for Group II and $69.0 \pm 43.6$ for Group III; data is expressed in nanocuries $\pm 95 \%$ confidence intervals. The initial alveolar depositions of ${ }^{238} \mathrm{Pu}$ were estimated to be three times the amount present in the lung at one day following inhalation, based on the intratracheal instillation studies with the same ${ }^{238}$ Pu prepara tion, which demonstrated an approximate $70 \%$ loss of initially deposited ${ }^{238} \mathrm{pu}$ from the lung into the blood, tissues and excreta the first day afier instillation. Thus the initial alveolar depositions were caiculated as $5 \mathrm{nCi}$ for Group I, $18 \mathrm{nCi}$ for Group II and $230 \mathrm{nCi}$ for Group III. Microscopic Distribution of ${ }^{238} \mathrm{Pu}$ - Nutoradiograms of lung sections at vie day after inhalation of ${ }^{238} \mathrm{Pu}$ showed that the ${ }^{23 S_{\mathrm{P}}} \mathrm{P}$ was associated mostly with the alveolar septae. Plutonium aggregates, as evidenced by alpha stars on the autoradiograms, were rare. Most a? pha tracks in the lung rere spread randomly as single tracks inroughout the alveolar tissue (Figure 4). Little evidence of alveolar ${ }^{238} \mathrm{Pu}$ was present on autoradiograms of lung at one year or longen after exposure. The little remaining activity was concentrated 
mostly with hemosiderin-like pigment granules located in peribronchiolar and perivascular regions of the lung.

Plutonium-238 was diffusely distributed in other soft tissues, with alpha stars, indicative of particulate plutonium, being very rarely seen. Plutonium was not concentrated in pulmonary Iymph nodes. Plutcnium in the femur was initially concentrated on periosteal surfaces. A year or longer after exposure, the ${ }^{238} \mathrm{Pu}$ wis found distributed diffusely throughout the bone matrix, with some irregular concentration of activity being found in vascular areas of bone and in some regions of the bone marrow. Loose aggiegations of ${ }^{238} \mathrm{Pu}$ associated with hemosiderin-iike granules were observed at a year or longer after exposure in liver, spleen and bone marrow tissues. Autoradiographic exposures of up to two months were required to detect the ${ }^{238} \mathrm{Pu}$ activity in these soft tissues from Groups I or II a month or longer after exposure.

Tissue Distribution - Based on studies of ${ }^{2} 38 \mathrm{Pu}$ behavior following intratracheal instillation, from $60-70 \%$ of deposited ${ }^{238} \mathrm{Pu}$ was lost from the lungs during the first day postexposure and $90 \%$ by 39 days postexposure (Figure 3). Only about $7 \%$ of the estimated initial alveolar deposition of inhaled ${ }^{238} \mathrm{Pu}$ remained in the lung at 300 days postexposure, docreasing to ahout $0.3 \%$ by 600 days postexposure (Figure 5 ).

The liver burden was about $0.7 \%$ of initially deposited activity at one year postexposure, decreasing by about half by the second year. The body burden of ${ }^{238} \mathrm{Pu}$ was about $25 \%$ of initially deposited dose at 300 days postexposure, decreasing to about $12 \%$ by 1000 days postexposure.

Detailed analyses of ${ }^{238} \mathrm{Pu}$ contents in tissues were performed on a 11 
rats that died during the first 700 days postexposure (62/92 exposed rats). Total body burden of ${ }^{238} \mathrm{Pu}$ was determined in the remaining 30 animals which died after 700 days postexposure. Average ${ }^{238} \mathrm{Pu}$ contents in tissues on at least 19 rats per group are shown in Table I. About $1 \%$ or less of the intial7y deposited ${ }^{238} \mathrm{Pu}$ was present in either the lung, Tiver or gastrointestinal tract tissues and $0.5 \%$ or less was found in either the spleen, kidney, skin or extra-puimonary thoracic tissues. The greatest concentration of 238 pu nccurred in the skeletor; $38-68 \%$ of the terminal body burder. or $9-18 \%$ of the initial ${ }^{238} \mathrm{Pu}$ body burden. An average of $16-32 \%$ of initial ${ }^{238} \mathrm{Pu}$ was present in a.1 tissues and organs of the rats during this time; this amounted to an average body burden at 200-700 days postexposure of 1.1 nCi ${ }^{238} \mathrm{Pu}$ (Group I), $5.6 \mathrm{nCi}$ (Givup II) and $32.7 \mathrm{nCi}$ (Group III); an average of $37 \%$ (Group I), 30\% (Group II) and 24\% (Group III) of terminal body burden was present in a 7 ? other tissues, other than lung, thoracic contents, 7 iver, G.I. tract, spleen, kidnev. skin or skeleton. The mean terminal body burdens for al1 92 rats were $0.80 \mathrm{nCi}$ (Group I), $4.11 \mathrm{nCi}$ (Group II) and $27.8 \mathrm{nCi}$ (Girnup III).

Dose Accumulation - The absorbed radiation doses accumulated by the lung and skeleton were calculated from data on the ${ }^{238} \mathrm{Fu}$ conients of tilese tissues. Dcse calcu?ations foi lung and skeleton were determined from organ or iissue weights, ${ }^{238} \mathrm{Pu}$ contents and lifespans in each group. Thus radiation ciose (rads) $=\mathrm{nCi}{ }^{238} \mathrm{Pu} / \mathrm{gm} \times$ rads $/ \mathrm{nCi} / \mathrm{gm} /$ day $\times$ Tifespan (days). The average accumulated radiation doses at 700 days after exposure to ${ }^{238} \mathrm{Pu}$ were for lung 9 rads (Group I), 32 rads (Group II) and 375 rads (Group III), The radiation dose accumulated by skeleton was determined by averaging the amount 
of ${ }^{238} \mathrm{Pu}$ in skeleton. skeletal weight (assumed to be $6 \%$ of body weight at death) and lifespan. For skeleton, the accumulative mean radiation doses were 2 rads (I), 20 rads (II) and 150 rads (III). The radiation dose calculatione for lung ${ }^{a}$ were determined or the basis of ${ }^{238} \mathrm{Pu}$ lung retention curves. An example of derived dose curves for lung are shown in Figure 6. About half the radiation dose delivered to the lung accumulated in the first month and $80 \%$ the first 4 months after inhalation exposure. Little further dose accumulation occurred in the lung after the first year postexposure. The dose delivered to the skeleton accumulated throlighout the lifespan of the rats due to the tenacious retention of ${ }^{238} \mathrm{Pu}$ in skeletal tissue.

Toxicity of Inhaled ${ }^{238} \mathrm{Pu}$

Mortality - The median survival time for the tiree groups of exposed rats were all less than for the unexposed control rats. Control animals exhibited a median survival time of 825 days, those in Group I 650 days, those in Group II 675 days and those in Group III 550 days. Exposure to the plutonium aerosol cccurred at about 70 days of age. Mortality rates were similar for all groups (Figure 7). Even at the highest exposure level of ${ }^{238} \mathrm{Pu}$ (Group III), the average amount of lifespan shortening amounted to only $20 \%$ of expected lifespan: based on the survival times of unexposed control aritinals.

Cause of Death - The immediate cause of death or morbidity in most of the rats was difficult to ascertaiin. of the ${ }^{238} \mathrm{Pu}$ exposed rats, $18 \%$ died from malignant, metastatic or infiltrative tumors involving vital organs;

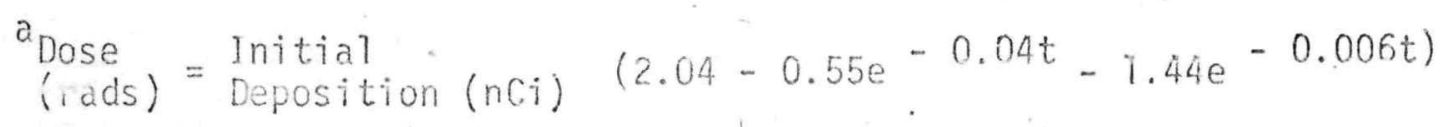


4\% of unexposed control rats died from such tumors. Large, multiple mammary tumors were common in all groups, but did not involve vital organs. Fatty degeneration of the liver with peribiliary inflarmation, liver cell necrosis, bifiary hyperplasia and reactive liver cell hyperplasia were commonly seen in aging rats. Chronic nephritis with cortical inflammatory infiltrates and epithelial hyperplasia and dialated cortical tubules were very common in old rats. Adenocystic hyperplasia of the uterus and hemorrhagic degeneration of adrenal cortex were frequently oisserved.

Evidence of chronic murine pneumonia was seen in most animals, irrespective of treatment. About $5 \%$ of all rats exhibited bronchiectatic cavitation and $10 \%$ exhibited discrete, consolidative inflammatory lesions in one or more lobes of the lung. Peribronchiolar lymphoid hyperplasia and fibrosis were seen in most aniliais. Fibrosis and extensive thickening of the alvaolar septae were seen only in some animals in Group IIT. However, patchy interstitial pneumnitis with septal infiltration of inflammatory cells wes nnt uncommon. Animals with lung tumors did not appear to be any more severely affected by chronic murine pneumionia than those without 7 ung tumors.

Tumor Formation: Mammary Tumors - Large numbers of mammary tumors arise spontuneously in aging rats. A higher incidence of mammary tumors occurs in female rats which live ronger than 700 c'ays. The incidence of mammary tumors in female Sprague-Dawley rats ranges from $55-85 \%(19-20)$.

In cur study, mammary tumors constituted the greatest number of ubserved tumors. Mammary cumors were divided into benign fibroadenomas and malignant adenocarcinomas. Evidence of metastasis of mammary adenocarcinomas was not seen since no re?ationship could be found between the incidonce of 
carcinomas found in other tissues or organs. For example, $16.3 \%$ of the 92 ${ }^{238} \mathrm{Pu}$ exposed rats had one or more mammary adenocarcinomas, white $27.2 \%$ exinibited carcinomus in other tissues or organs. Thus on a random distribution basis, $4 \%$ of rats with extra-mammary carcinomas would be expected to also have mammary adenocarcinomas. Actually $4.3 \%$ of exposed rats exhibited both mammary avenocarcinomas and exira-mammary carcinomas, indicating no association with respect to metastatic growith between the two classes of epithelial tumors. Furthermore, no association was found between mammary adenocarcinomas and bronchiolo-alveolar adcrocarcinomas of the lung.

The incidence of mammary tumors in unexposed rats was not different from that found in ${ }^{238} \mathrm{Pu}$ exposed rats (Table II). About one in every five mammary tumors was an adenocarcinoma. The incidence of mammary adenocarcinomas ranged from $10 \%$ to $20 \%$ in all groups, of fibroadenomas from $44 \%$ to $58 \%$ and of a 17 mammary tumors, from $60 \%$ to $73 \%$. No difference was seen in the time of first appearance of mammary tumors or in their rates of induction. irrespective of treatment.

iumor Formation: Lung Tumors - The incidence of iung tumors in all grouns exposed to ${ }^{238} \mathrm{Pu}$ was greater than in unexposed control rats (Table II). Only one lung tumor was found in control animals, a large cell undifferentiated carcinoma which exhibited a primary growth in the lung periphery and had inciltrated throughout the lung, particularly within pulmonary blood vessels (Figure 8). No undifferentiated carciromas were found in rats exposed to ${ }^{238} \mathrm{Pu}$. The dominant tumor type in exposed rats were bronchiolo-alveolar adenocarcinomas, which comprised about $75 \%$ of all lung tumors seen in this study. Bronchiolo-alveolar adenocarcinomas were characteristically papillary 
in structure, fairly well localized in the periphery of the lung lobes and exhibited varying degrees of infiltration of tumor cells at the interface of normat lung tissue and tumor (Figures 8-9). Four of the bronchiolo-alveolar carcinomas exhibited wide spreat metastatic growths in the lung. One exposed rat exhibited a large sclerosing squamous ceil carcinoma, similar to an epidermoid carcinoma (Figure 8). Two tumors in the lung were of mixed ce? type, containirg both squamous carcincma cells and adenocarcinoma cells. One iymphosarcoma was found in an exposed rat lung.

The incidence of lung tumors in unexposed control animals was $1.7 \%$ $(1 / 92)$, in Group I, 6.6\% (2/30), in Group II, 23.3\% (7/30) and in Group III, $25 \%(8 / 32)$. The incidence of lung tumors in Groups II and III was significantly greater than in control rats at the $99.9 \%$ level of confidence. Although the percentade of rats in Group I with lung tumors wius six times that in controls, statistical significance was not eviderit due to the low number of tumors found in Group I (Table III).

Tumor Formation: 0ther Tumors - of a11 the 34 extra-mammary tumors found in rats exposed to ${ }^{238} \mathrm{Pu}, 50 \%$ were found in the 7 ung and $50 \%$ in cther areas of the body. Several endometrial carcinomas were found in the uterus of exposed rats. Other carcinomas were found originating from the ovary, renal pelvis, urinary biadier mucosa, skin, intestinal mucosa, and exocrine portion of the pancreas. Non-epithelial tumors comprised one pheochromorytoma of the adrenal gland, a leiomyosarcoma of the uterus, a reticulum cell sarcoma of an abdominal lymph node, a lymphosarcoma of the spleen and three osteogenic sarcomas (Table II). The osteosarcomas all originated from the lumbar region of the spine, all caused paralysis of the 
hind legs, all found only in the highest exposure Group III and all metastasized to the lung (Figure 9). The accumulated radiation doses for animals with osteosarcoma were 51 rads, 96 rads and 152 rads. Two cases of myelogenous Teukcmia and one case of transitional cell carcinoma of the renal pelvis were found in unexposed rats (Table II). No leukemias were observeu in rats exposed to ${ }^{238} \mathrm{Pu}$.

Tumor Formation: A71 Non-Mammary Tumors - The incidcnce and rate of induction of al1 non-mammary tumors was clearly related to the amoliii of ${ }^{238} \mathrm{Pu}$ initially deposited in the lung (Figure 10). The incidence of non-mammary tumors in unexposed controls was 4.3\%; in Group I, $26.7 \%$; in Group II, 36.6\%: and in Group III, 46.8\%. The total incidence of non-mammary tumors in all groups was significantly greater than control tumor incidence at the $99.9 \%$ level (Table III). About 75\% of a 11 non-mammary tumors in a.11 groups originated from epithelial tissues.

of all $92{ }^{238} \mathrm{Pu}$ exposed rats, 28 developed 34 different tumors. Multiple tumors of different types were found in 4 rats. In one rat, a lymphosarcoma of the spleen, carcinoma of the uterus and bronchiolo-alveolar adenocarcinoma of the iung were found at autopsy. A particularly interesting animal was one that developed an osteogenic sarcoma in the lumbar vertobrae that matastasized to the lung, a focal bronchiolo-alveolar adenocarciroma and a transitional cell carcinoma of the urinary bladder which metastasized to the kidney and thoracic 7ymph nodes (Figure 9).

\section{DISCUSSION}

Crushed ${ }^{238} \mathrm{PuO}_{2}$ microspheres suspended in saline were largely in a. monomeric form when delivered by inhalation to our rats. The experimental 
cvidence is as follows: (1) over $70 \%$ of the plutnnium preparation in saline with ultrafilterable; (2) the aerosol exhibited a very small particle size of about $0.02 \mu \mathrm{m}$, which lacked the sharp borders and homogeneous electron density under the electron microscope, characteristic of insoluble $\mathrm{PuO}_{2}$ particles; (3) autoradiograms of the lung one day after innalation of ${ }^{232}$ pu showed a highly uniform distribution of mostiy single tracks distributed in the alveolar tissue with very few alpha stars, indicative of particulate $\mathrm{PuO}_{2}$, being seen in the lung sections: (4) the lung retention of ${ }^{238}$ pu was very short with $>50 \%$ of deposited activity being lost from the lung the first day after deposition of ${ }^{238} \mathrm{Pu}$ and $90 \%$ the first month; (5) the remaining ${ }^{238} \mathrm{Pu}$ was rapidly translocated from lung to blood and then mostly to ske? eton.

Several conclusions regarding certain aspects of piutonium toxicology are indicated by the results of this study:

1. Leukemia was not induced by inhaled ${ }^{238} \mathrm{Pu}$, al though it was observed in two unexposed control rats. Among many studies reported only one siliuly has shown leukemia incidence to be related to plutonium deposition in the rat $(21)$.

2. Similar to previous observations in rats and dogs, following skeletal deposition of ${ }^{239} \mathrm{Pu}{ }^{(22)}$, osteosarcomas were observed in Pu treated animals but only the highest exposure level (Group III) and only at accumulated radiation doses of greater than 50 rads to the skeleton.

3. Exposure of fema? s nats to ${ }^{238} \mathrm{pu}$ had no effect on the incidence of naturally occurring, spontaneous mammary tumors. The effect of ${ }^{238}$ pu was on 


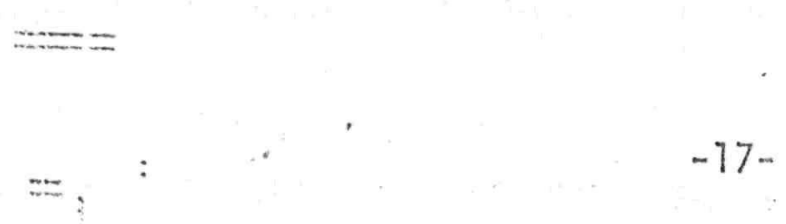

the induction of tumors, rarely observed spontaneousily in untreated animals.

4. About three-forths of the ${ }^{238} \mathrm{Pu}$ induced tumors were of epithelial origin. The dose delivered to the epithelial tissues may be considered as fairly uniform and of comparable $70 \mathrm{w}$ magnitude based on the analysis of ${ }^{238} \mathrm{Pu}$ contents in tissues and examination of tissue section on autoradiograms. We shall examine this point further with respect to the lung.

5. rumors in ${ }^{238} \mathrm{Pu}$ exposed rats are found in many oiher tissues, other thar in the lung or bone. The inciuense of tumors in any one tissue or organ, other than in lung and skeleton, is low foi any particular experimental group. However, summing up the total number of such tumors in organs as the uterus, ovary, urinary bladder, G.I. tract, kidney, skin or pancreas shows a linear reiationship between increasing tumor induction and increasing ${ }^{238} \mathrm{Pu}$ deposition as compared to unexposed control animals.

The physical characteristics and distribution of radiations from radic. nuclides deposited in tissues have an important bearing on their carcinogenic effects. A good example is the comparison in rats of the carcinogenicity of beta-emitting radionuclides with alpha-emitting nuclides deposited in the lung (Figure 11). The average energy of beta-emitters tested in these studies was from 1-z mev. The average energy of alpha emissions from plutonium was about 5 mev or not all that much greater than for jeta particles. The basic differerce between the two types of radiations is in their Linear Energy Transfer (iET) with beta particles exhibiting LET's of less thain 100 evium while alpha particles averaged LET's of about 100,000 ev/um. Beta particles penetrate millimeters in tissue while alpha particles penetrate less than $50 \mu \mathrm{m}$. Ohvious ly the radiation close around an alpha enitter is much greacer than the 
dose around a beta emitter. The incidence of lung tumors in rats is much greater per rad of dose delivered to the lungs for alpha emitters than for beta emitters (Figure 11). The relative biological effectiveness (R.B.E.) for alpha emitters/beta emitters is about 30 based on the data shown in Figure 11.

What about comparing alpha-emitters which are diffusely distributed in monomeric form throughout the lung with concentration of alpha emitters into polymers or oxide particulates? The initial even distribution of inhaled ${ }^{238} \mathrm{Pu}$ in the lung parenchyma resulted in a comparatively large number of tumors in tie lung and in other tissues, at radiation doses that have not previously been shown to be carcinogenic. Unfortunately comparable studies with ${ }^{238} \mathrm{PuO}_{2}$ and ${ }^{239} \mathrm{PuO}_{2}$ particles in rats have not been published; such studies are currently being carried out at BNW over a five-fold range order of magnitude dose schedule. Studies by Moskalev (1972) and associates with inhaled ${ }^{239} \mathrm{Pu}$ citrate or ammonium ${ }^{239}$ Plutonyl pentacarbonate have shown an apparent significant increase in the incidence of lung tumors in rats at cumulative absorbed radiation doses to the lung of about 50 rads. Studies in rats reported here show lung tumor formation at 9-32 rads following inhalation of ${ }^{238} \mathrm{Pu}$. It is possible that a share of this ${ }^{239} \mathrm{Pu}$ was in a polymeric form resulting in greater heterogeneity of dose distribution in the lung than with our ${ }^{238}$ ru. This may accouni for the greater number of lung tumors or the lower doses reguired to induce lung tumors for ${ }^{238} \mathrm{Pu}$ than for ${ }^{23 y} \mathrm{Pu}$. The greater mass of ${ }^{239} \mathrm{Pu}$ compared to ${ }^{238} \mathrm{Pu}$ required for identical radiation doses in the lung may in part result in greaier polymeric association of ${ }^{239} \mathrm{Pu}$ in the aerosol and physiologically in the lung than for ${ }^{238} \mathrm{Pu}$. 
: The influence of dose concentration may be more evident when dealing with relatively insoluble ${ }^{239} \mathrm{PuO}_{2}$ particles. True well-defined "hot spots" result from pulmonary deposits of such particles. The number of pulmonary cells hit by alpha particles from large Pu particles will be iess than the numiver oi cells hit from alpha emissions of smaller particles of the same total mass. Pulmonary cells adjacent to $\mathrm{PuO}_{2}$ paricies will be hit many times by alpha emissions with resultant "overkill" and "wasted amounts of radiation" from a biological-effect point of view. The probability of mu?tiple hits on any one cell following deposition of the same amount of Pu in the monomeric form, would be much less.

To further complicate the picture, $\mathrm{PuO}_{2}$ particles will be rather tenaciously retained in the lung while the ru monomer may be rapidly translocated from the Tung to bone and other soft tissues or excreted in the urine. Pu0 particles in the lung will be gradually concentrated towards the periphery of the lung resulting in high radiation doses delivered to subpleural regions of the lung (8). The result is often severe fibrosis in those areas further decreasing the number of epithelial "target" ce?"s which may ba hit by alpha emissions.

Finally, the nature of the particle size dictribution in the aerosol deposited in the deep lung will greatly complicate the dose distributivin ' pattern. Autoradiographic determination of $239 \mathrm{PuO}_{2}$ particle size distribution in aiveoiar macrophages washed from the lungs of exposed rats within 30 days postexposire, showed that over $80 \%$ of the ${ }^{239} \mathrm{Pu}$ activity was consenuruiad in large particles, which represented only $2 \%$ of the deposiceu particles $(9)$. The dose-distribution in beagle dogs developing lung tumors from inhaled ${ }^{239}$ PuO $_{2}$ particles (4) is probably sinilar in the degree of dose contribution 


$$
\because:=
$$

by a relatively few larger sized $\mathrm{PuO}_{2}$ particles. Thus the disproportionate concentration of plutonium in relatively few particles of larger size, the physiological concentration of $\mathrm{PuO}_{2}$ particles in subpleural artas of the luny and the concentration of Pu in dioxide particles or in polymers of Pu all result in "wasted" dos depostition in the luing. This conclusion is true only if one assumes that hitting of larger numbers of target cells (those which develop into tumors) will increase the probability for inducing a tumor. Studies with ${ }^{238} \mathrm{Pu}$ monomer suggest that spreading the plutonium activity evenly throughout the lung may be more carcinogenic than depositing the activity as insoluble particulates in the lung. 
1. K. G. Scott, D. J. Axelirod, J. Crowley and J. G. Hamilton. Deposition and fate of plutonium, uranium and their fission products inhaled as aerosols by rats and man. Arch. Pathol. 43, 31-54 (1949).

2. R. A. Erokhin, N. A. Koshurnikova, V. K. Lemberg, A. P. Nifatov and A. A. Puzyrev. Lung tumors in rat following intratracheal introduction of soluble piutonium-239 compounds. Gig. Tr. Prof. Zabol, 5, 61 (1969).

3. Y. I. Moskalev. ${ }^{239}$ Pu: Problems of its biological effect. Health Phys. 22, $723-729(1972)$.

4. J. F. Park, W. J. Bair and R. H. Busch. Progress in beagle dog studies with transuranium elements at Battelle-Northwest. Health Priys. 22 , 803810. (1972).

5. L. A. Temple, S. Marks and W. J. Bair. Tumors in mice after pulmonary deposition of radioactive particles. J. Radiat. Biol. 2, 143-156 (1960).

6. H. Lisco. Autoradiographic and histopathologic studies in radiation carcinogenesis of the 1ung. Lab. Invest. 8, 162-170 (1959).

7. C. L. Sanders and J. F. Park. Pulmonary distribution of alpha dose from ${ }^{239} \mathrm{PuO}_{2}$ and induction of neoplasia in rats and dogs. In Inhaled farticles III (C. N. Davies (ed.) Vol. 1, pp 489-498. Unwin Brothers Ltd., 01d Woking, England, 1971

8. W. J. clarke and W. J. Bair. Plutonium innalation studies, VI. Pathologic effects of inhaied plutonium particles in dogs. Health Phys. $10,391-398(1964)$.

9. C. L. Sanders. Deposition patterns and the toxicity of transuranium elements in lung. ilealth Phys. 22, 607-615 (1972). 
10. B. O. Stuart, J. W. Bair, W. J. Clarke and E. B. Howard. Acute toxicity of inhaldid plutonium oxide-238 and -239 in rats. Air Force Weapons Laboratory Technical Report Ko. AFWL-TR-68 49 (1968).

11. J. F. Pak, E. B. Howard and W. J. Bair. Acute toxicity of inhaled ${ }^{238} \mathrm{PuO}_{2}$ in beagle dogs. Air Force Weapons Laboratory Technical Report No. AFKL- 7 - $69-75$ (1969).

12. C. L. Yulve, F. R. Gibis and P. E. Morrow. Dose-related Tocal and systemic effects inhaled plutonium-238 and plutonium-239 dioxide in dogs. Radiat. Nes. 44, 821-834 (1970).

13. W. J. BaE Plutonium Inhalation Studies. BNML-122I, Battelle-Nurthwest, Richlanc, Rash., February, 1970.

14. A. Lincerisum and $W$. Westfall. Colloidal properties of plutonium in dilute acueous solution. Int. J. Appl. Radiat. Isotopes 16, 545-553 (1963).

15. M. A. Passont, W. L. Holley and W. D. Burnett. The effect of particle size on siman distribution of radioactive macirial deposited in the lungs. Bearth Phys 22, 143-148 (1972).

16. S. G. AEramanon, D. G. Carfagno and B. R. Kokence. Plutorium-238 isotopic 1 form data sheets, Monsanto Research Corporation, Mound Laborate, Miamisburg, Ohio, MLM-1564. October, 1968.

17. H. Cemition and J. A. Watson. Bronchogenic carcinoma from radioaciive barium siveate. AMA Arch. Ind. Health 17, 230-235 (1953).

18. R. F. Ketwoy and G. J. Powers. Determination of plutonium in biological materials ay extraction and liquid scintillation counting. Analyt. Chem. 42, $419-2+2$ (1970).

19. S. P. Shew. Mammary tumors in control rats. Literature Tabulation. Toxi. Pharmacoi. 22, 562-588 (1972). 
20. R. K. Davis, G. T. Stevenson and K. A. Busch. Tumor incidence in normal : Sprague-Dawley female rats. Cancer Res. 16, 194-797 (1956).

21. J. P. M. Bensted, D. M. Taylor and F. D. Snwby. The carcinogenic effects of americium 241 and plutonium 239 in the rat. Brit. J. Radiol. 38, 920-925 (1965).

22. W. S. S. Jee. Distribution and Toxicity of ${ }^{239} \mathrm{Pu}$ in Bone. Heaith Phys. 22, 583-595 (1972).

23. H. Cember, J. A. Watson and A. A. Spritzer. Bronchogenic carcinoma from radioactive cerium fluoride. AMA Arch. Ind. Health 19, 14-23 (1959).

24. H. Cember. Emperical establishment of cancer-associated dose to the lung from ${ }^{144}$ Ce. Health Phys. 10, 1177-1180 (1964).

25. N. N. Kurshakova and A. E. Ivanov. A model of experimental lung cancer caused by intratracheal introduction fo radioactive cerium. Bull. Exp. Biol. Med. (USSR) 54, 787-793. (1963).

26. T. A. Kocheikuria, G. A. Avrunina and N. D. Sagaidak-Chernyak. Experimeriza? lung cancer induced with radioactive compounds $\mathrm{p}^{32}$, Au ${ }^{198}$ and $\mathrm{Fe}^{5 y}$. Acta Unio Int. Contra Cancrum 19, $684-686$ (1963). 


\section{FIGURE LEGEND}

Figure 1. Electron micrograph of aerosolized ${ }^{2}{ }^{3} \mathrm{Pu}$ in physiological saline. The carbon coated grids were washed with distilled water to remove sodium chioride crystais prior to taking the micrograph. Xi55,000

Figure 2. Excretion of intratracheally instilled ${ }^{238} \mathrm{Pu}$ in urine and feces. Each data point is a mean from four rats.

Figure 3. Tissue distribution of intratracheally instilled ${ }^{238}$ Pu. Curves were drawn by eye.

Figure 4. Autoradiogram of lung (Group III) taken at one day after inhalation of ${ }^{238}$ Pu. Exposure time of autoradiogram was three days. Views from two areas of the iung are shown. $\times 220$

Figure 5, Retention of pulmonary deposited ${ }^{238} \mathrm{pu}$ in the Tung. Data for the first 10 days after deposition is following intratracheal instillation; data for 200-800 days after donostition is following inhalation.

Figure 6. Cumiative radiation dose to the iung after inhatation of ${ }^{238}$ Pu. Method of calculation is described in the' text.

Figuie 7. Cumulative mortality of controi and ${ }^{238} \mathrm{Pu}$ exposed rats.

Figure 8. Puirionary carcinomas found in the lung of rats.

A. Bronchiolo-alveuiar adenocarcinoma, 790 days after inhalation of ${ }^{233} \mathrm{Pu}$. Tumor was metastatic throughout the lung. $\times 34$

B. Epidermoid carcinoma, 657 days after inhalation of ${ }^{238}$ pu. $\times 525$

C. Bronchiolo-alveolar adenocarcinoma, 757 days after inhalation of ${ }^{238}$ Pu. $\times 670$ 

Table 1. Distrithution of inhaled ${ }^{238} \mathrm{Pu}$ in ti sues of rats. Each value is a mean (>19 samples) of all autopsied animais taken at 200-700 days postexposure, $\pm 95 \%$ confidence intervals.

Table II. Tumor type, Tocation and incidence as a function of ${ }^{238}$ Pu exposure.

Table III. Incidence of tumors in the lung and all other tissues of the rat, other than mammary tumors, as a function of ${ }^{238} \mathrm{Pu}$ exposure. The level of significant difference of exposed rats from controls was determined by chi-square test. 
Table I. Distribution of rihaled ${ }^{238} \mathrm{pu}$ in tissues of rats. Each value is a mean $(>19$ samples) of al7 autopsied animals taken at 200-700 days postexposure, $\pm 95 \%$ confidence intervals.

\begin{tabular}{|c|c|c|c|c|c|c|c|c|c|}
\hline & & Group I & & & Group II & & & Group III & \\
\hline Tissue or Organ & $\mathrm{nCi}$ & $\begin{array}{c}\% \\
\text { Terminal } \\
\text { Body } \\
\text { Burden } \\
\end{array}$ & $\begin{array}{c}\% \\
\text { Initial } \\
\text { Boly } \\
\text { Burcien } \\
\end{array}$ & nCi & $\begin{array}{c}\% \\
\text { Terminal } \\
\text { Body } \\
\text { Burden } \\
\end{array}$ & $\begin{array}{c}\% \\
\text { Initial } \\
\text { Body } \\
\text { Burden } \\
\end{array}$ & nCi & $\begin{array}{c}\% \\
\text { Terminal } \\
\text { Body } \\
\text { Burden } \\
\end{array}$ & $\begin{array}{c}\% \\
\text { Initial } \\
\text { Body } \\
\text { Burden } \\
\end{array}$ \\
\hline Lung & $\begin{array}{r}0.05 \\
+0.04 \\
\end{array}$ & 4.56 . & 1.07 & $\begin{array}{r}\quad .75 \\
+0.14 \\
\end{array}$ & 2.71 & 0.86 & $\begin{array}{r}1.13 \\
\pm 0.65\end{array}$ & 3.47 & 0.55 \\
\hline Thoracic Contents & $\begin{array}{r}0.01 \\
+0.01\end{array}$ & 0.94 & 0.21 & $\begin{array}{r}0.02 \\
+0.01\end{array}$ & 0.36 & 0.71 & $\begin{array}{r}0.05 \\
+0.02\end{array}$ & 0.75 & 0.02 \\
\hline Liver & $\begin{array}{r}0.05 \\
\pm 0.03\end{array}$ & 5.16 & 7.14 & $\begin{array}{r}0.77 \\
\pm 0.70\end{array}$ & 3.12 & 0.59 & $\begin{array}{r}0.55 \\
+0.27\end{array}$ & 1.67 & 0.26 \\
\hline $\begin{array}{l}\text { Gastro Intestinal } \\
\text { Tissues }\end{array}$ & $\begin{array}{r}0.07 \\
\pm 0.04\end{array}$ & 6.60 & 1.46 & $\begin{array}{r}0.10 \\
\pm 0.04\end{array}$ & 3.78 & 0.56 & $\begin{array}{r}0.76 \\
+0.05\end{array}$ & 0.49 & 0.08 \\
\hline Spl zen & $\begin{array}{r}0.02 \\
\pm 0.02\end{array}$ & 7.89 & 0.42 & $\begin{array}{r}0.08 \\
+0.07\end{array}$ & 7.43 & 0.45 & $\begin{array}{r}0.76 \\
-0.07\end{array}$ & 0.49 & 0.08 \\
\hline Kidney & $\begin{array}{r}0.03 \\
\pm 0.02\end{array}$ & 2.83 & 0.63 & $\begin{array}{r}0.05 \\
+0.04\end{array}$ & 0.89 & 0.28 & $\begin{array}{r}0.77 \\
+0.06\end{array}$ & 0.33 & $\ddots^{0.05}$ \\
\hline Skin $\quad:$ & $\begin{array}{r}0.03 \\
+0.01\end{array}$ & 2.83 & 0.63 & $\begin{array}{r}0.10 \\
+0.05\end{array}$ & 1.78 & 0.56 & $\begin{array}{r}0.59 \\
+0.54\end{array}$ & 1.80 & 0.29 \\
\hline Skeleton & $\begin{array}{r}0.47 \\
\pm 0.75\end{array}$ & $3 \% .8$ & $\varepsilon .45$ & $\begin{array}{r}3.2 \\
+0.8\end{array}$ & 57.6 & 18.3 & $\begin{array}{l}22.2 \\
+4.4\end{array}$ & 67.9 & 10.7 \\
\hline $\begin{array}{l}\text { Total In ATI Tissues } \\
\text { And Organs }\end{array}$ & $\begin{array}{r}7.7 \\
+0.2\end{array}$ & 100 & 26.7 & $\begin{array}{r}5.6 \\
+0.9\end{array}$ & 100 & 37.7 & $\begin{array}{r}32.7 \\
+7.6\end{array}$ & 100 & 15.8 \\
\hline
\end{tabular}




$$
\begin{aligned}
& \text { Tabie II. Tumor type, Tocation and incidence as a function of } \\
& \text { 238pu exposure. }
\end{aligned}
$$

\begin{tabular}{c}
$: \quad$ Tumor \\
\hline
\end{tabular}

Mammary Fibroadenonia

Mammary Adenocarcinoma

Pulmonary Tumors

Bronchioio-alveolar Adenocarcinoma

Epidermoid Carcinoma

Mixed Carcinomas

Undifferentiated Carcinoma

Lymphosarcoma

Uterine Carcinomas

Uterine Leiomyosarcoma

Ovarian Carcinoma

Bladder Transitioná Cell Carcinoma

Adrenal Phonehromecytoma

Renal Transiticnal Coll Carcinoma

Cutuineous Squamous cell Carcinoma.

Intestinar Adenocuruinoma

Pancreatic Carcinoma

Áscominal Reticulum Cell Sarcoma

Spleenic Lymphosarcoma

Osteogenic Sarroma

Myelogenous Leukemia.

\begin{tabular}{ccccc} 
& \multicolumn{3}{c}{ Incidence of Tumors $(\%)$} \\
\cline { 4 - 5 } Control & Group I & Group II & Group III \\
57.6 & 53.3 & 50.0 & 43.7 \\
14.7 & 20.0 & 10.0 & 18.8
\end{tabular}

$\ldots .6$

13.3

27.9

$\cdots$

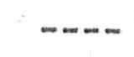

3.1

-..

6.6

1.)

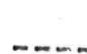

$\ldots$

3.3

6.6

3.3

3.1

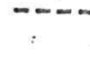

-....

3.3
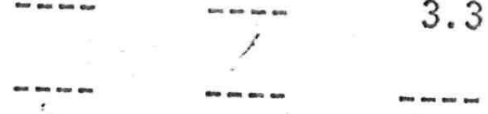

3.7

3.1

3.3

1.1

\section{3}

3.3

3.3

3.3

3.3
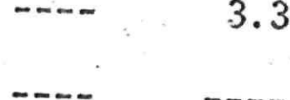

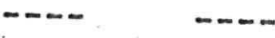

…-

3.1

$£ .4$

2.2 
C $\cdots$ 







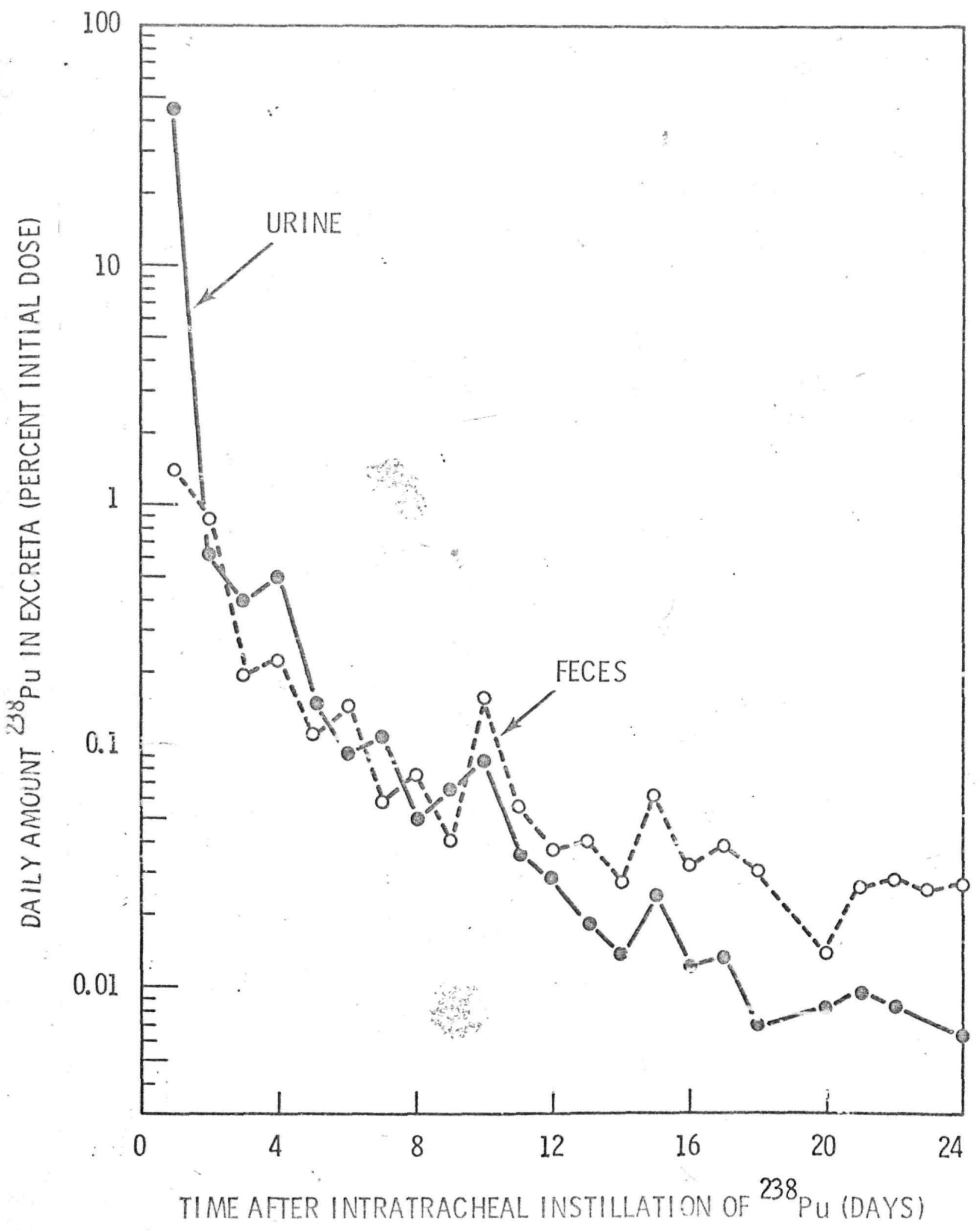




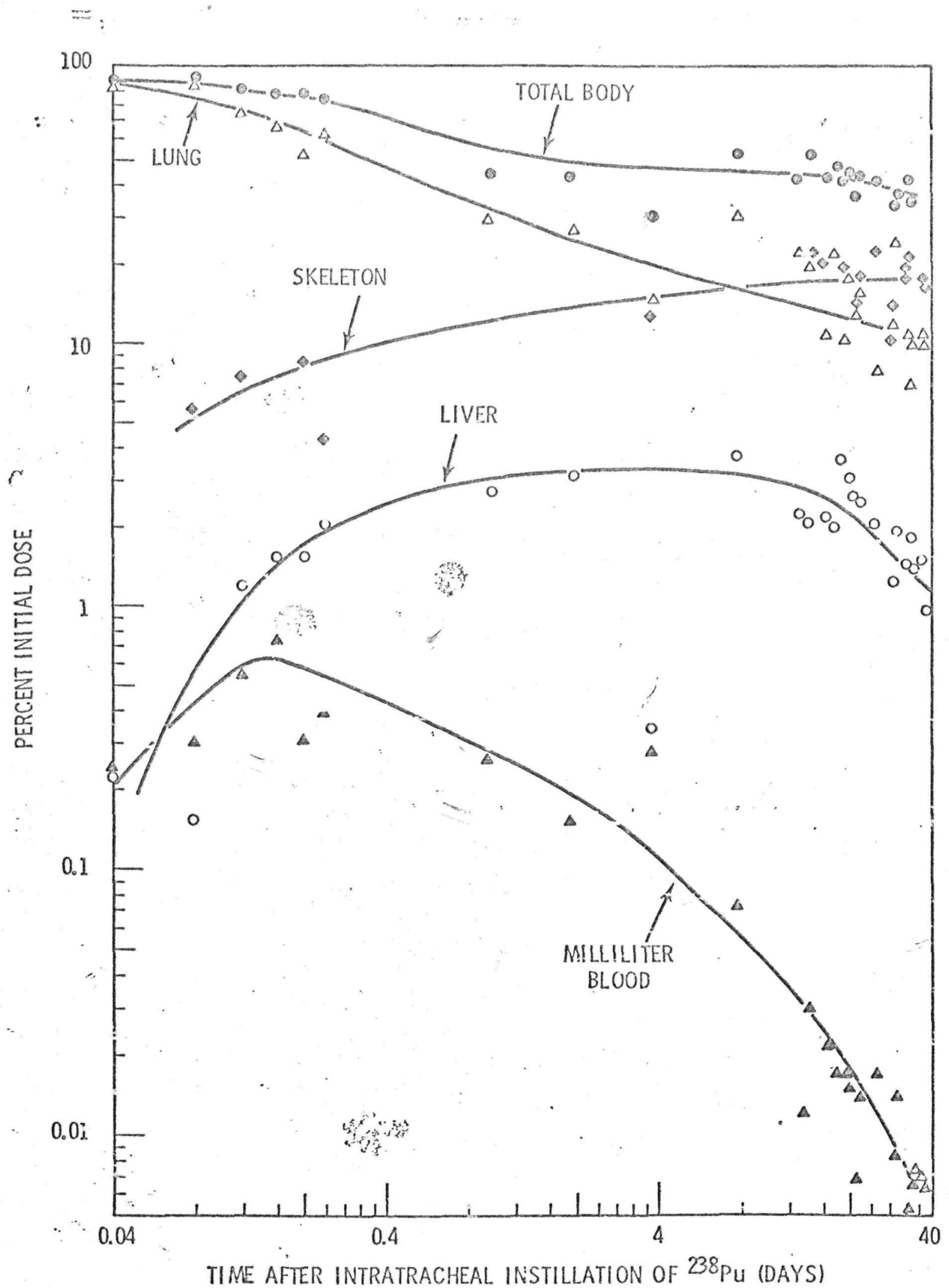




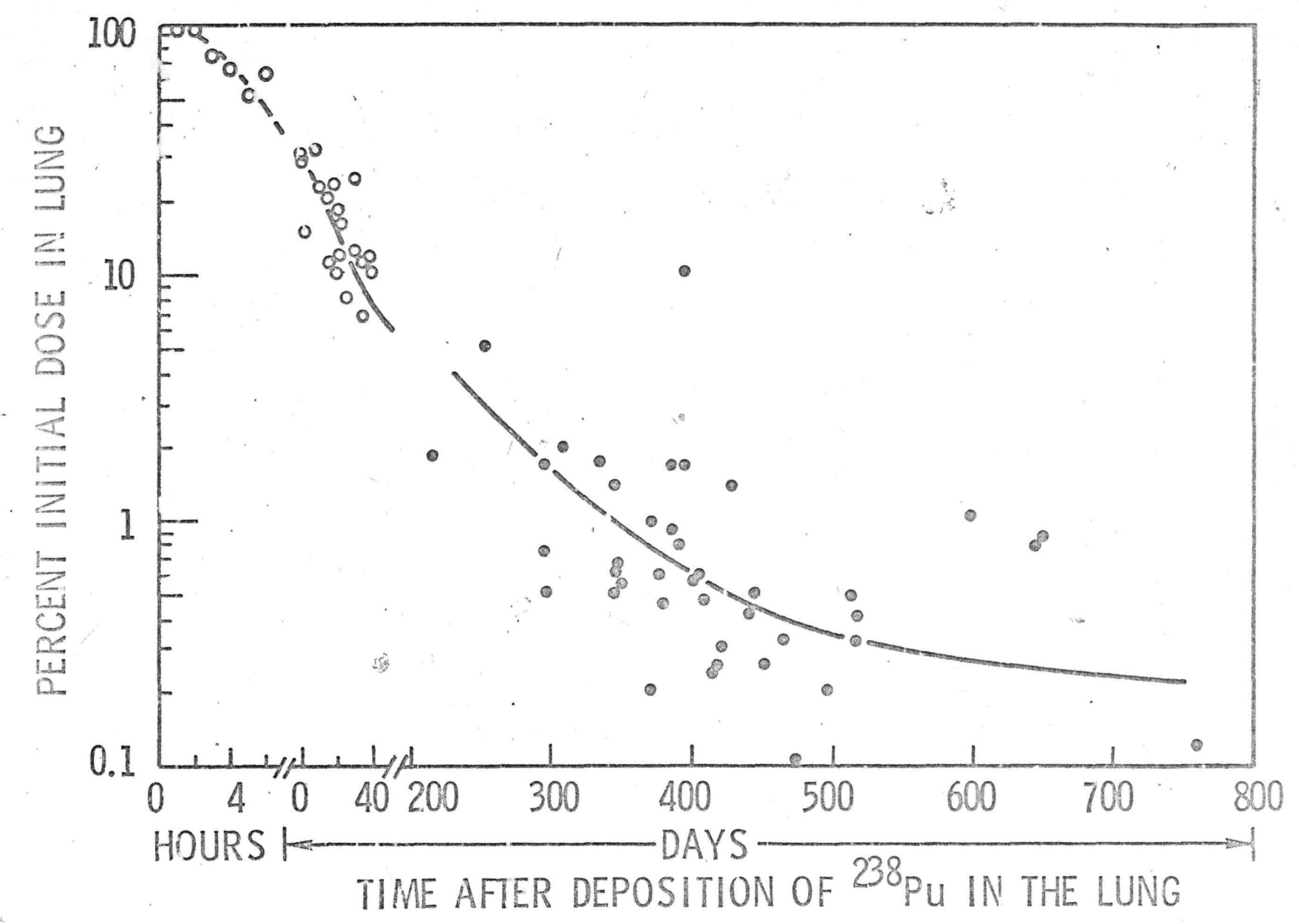




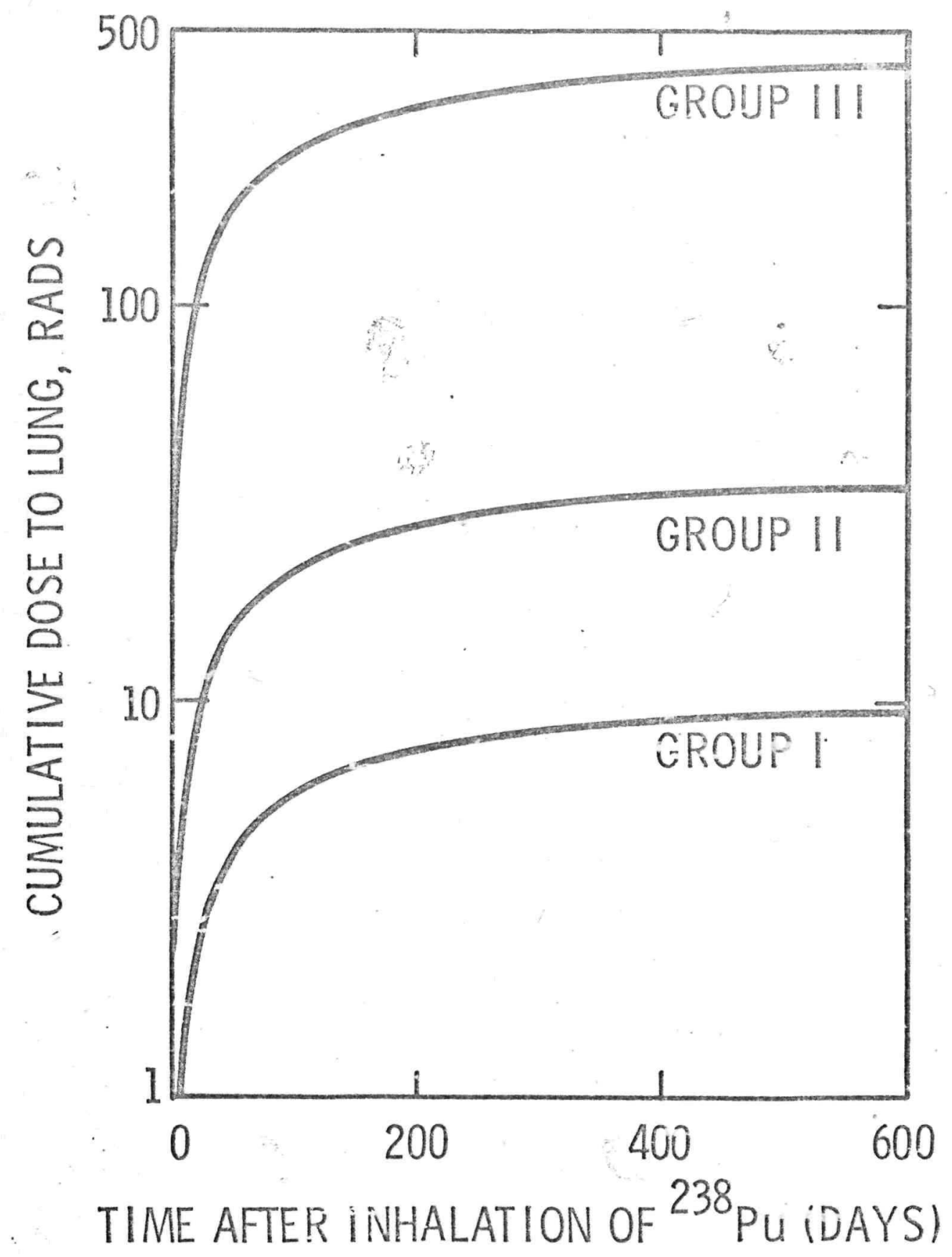




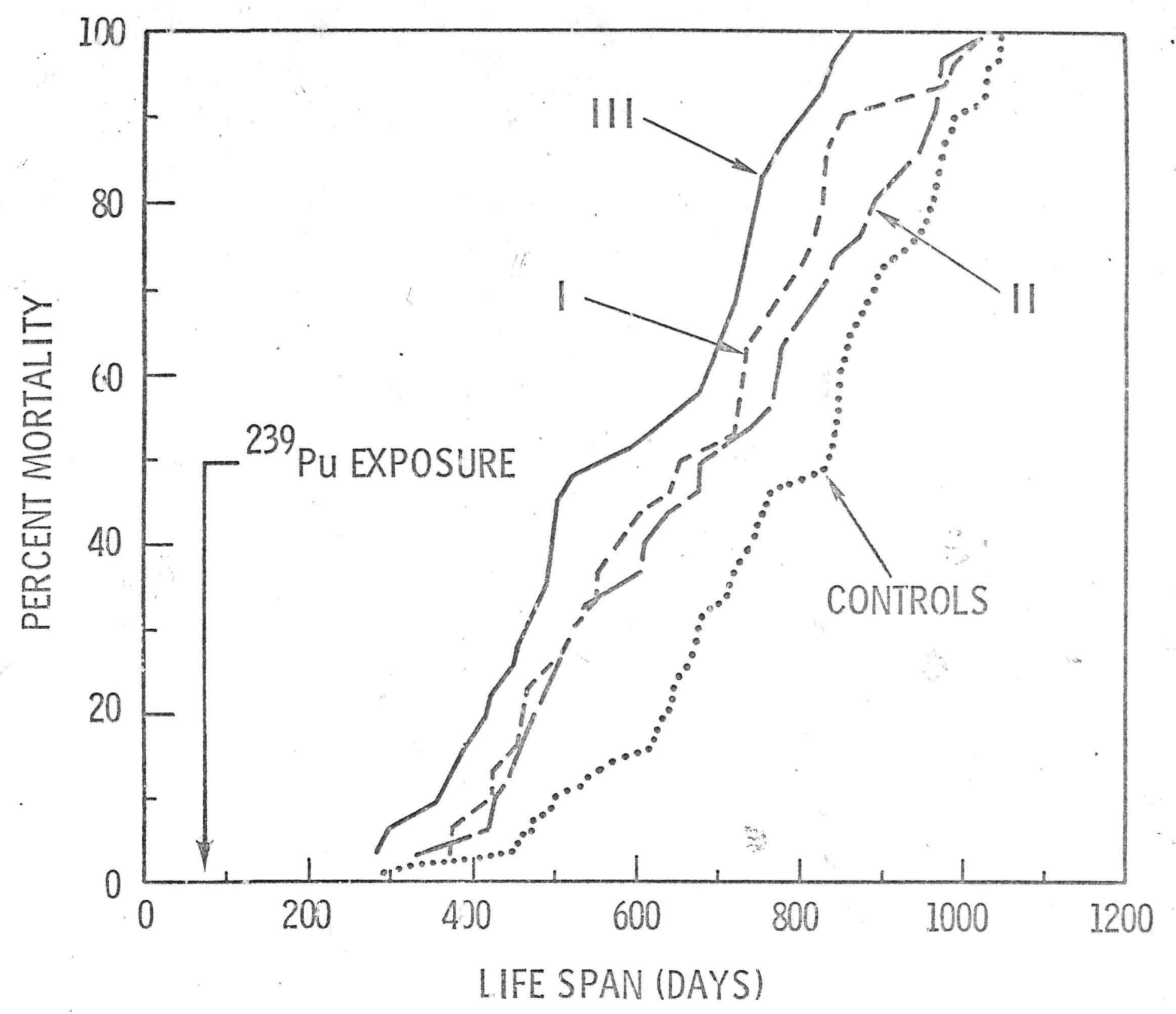



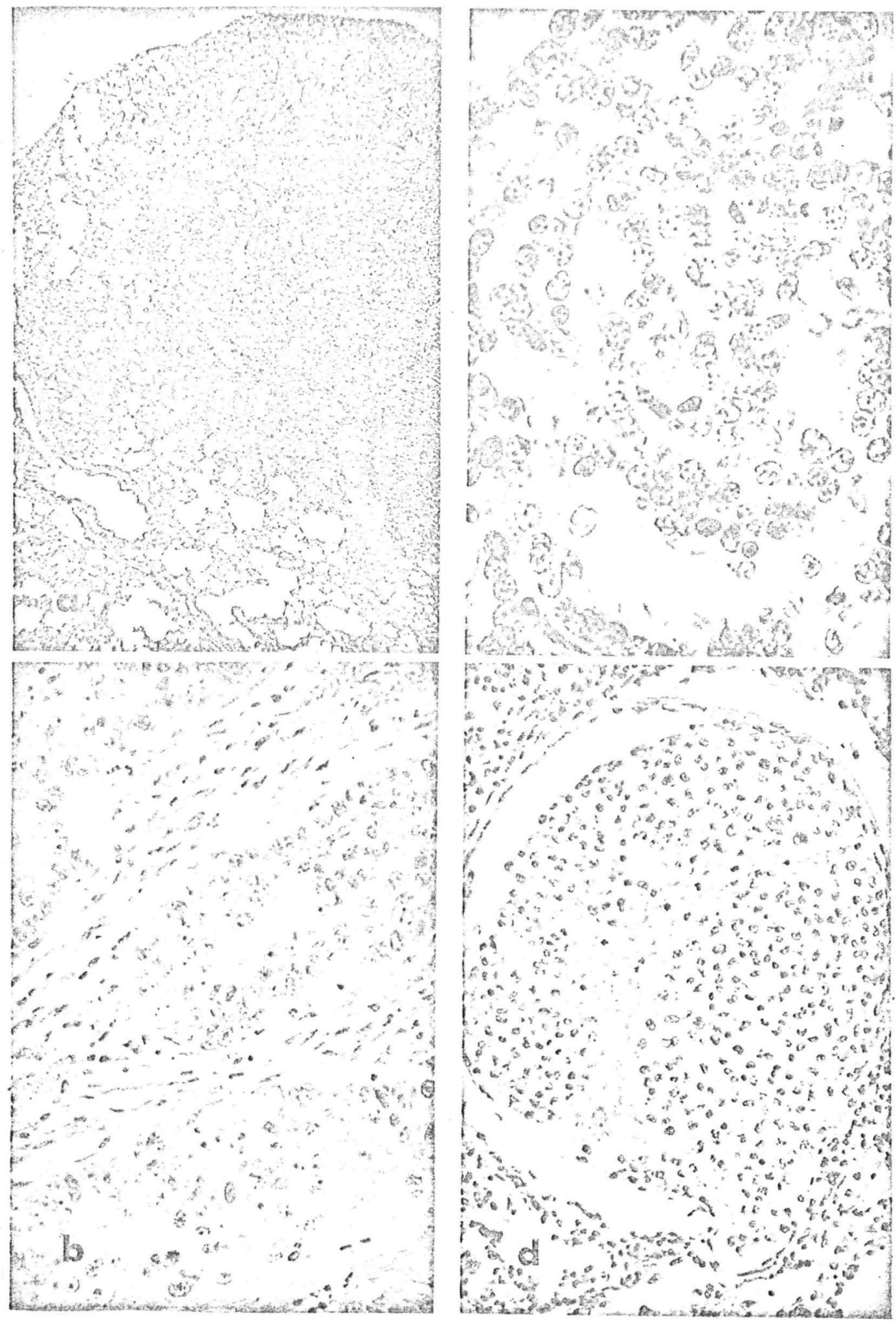

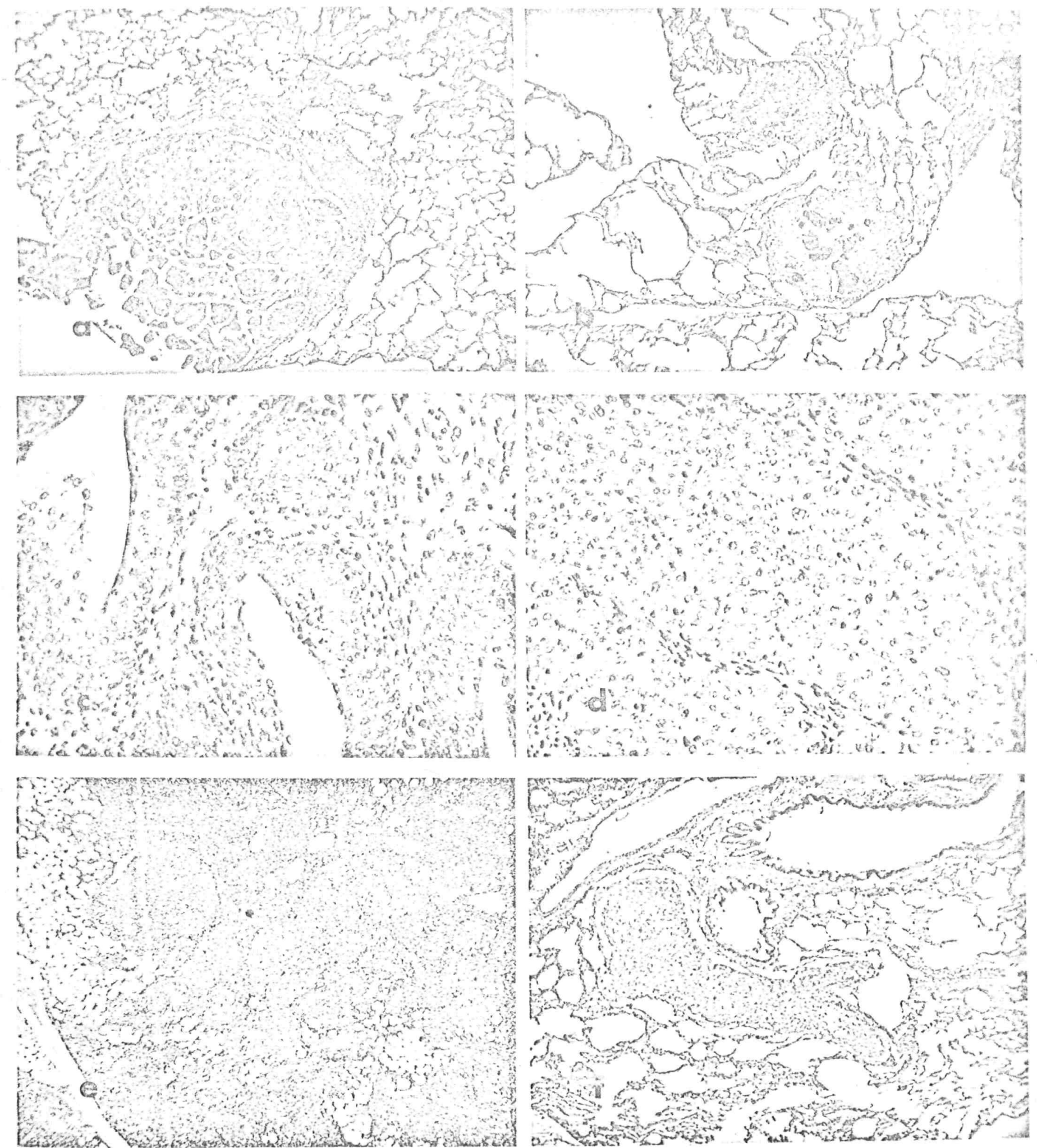


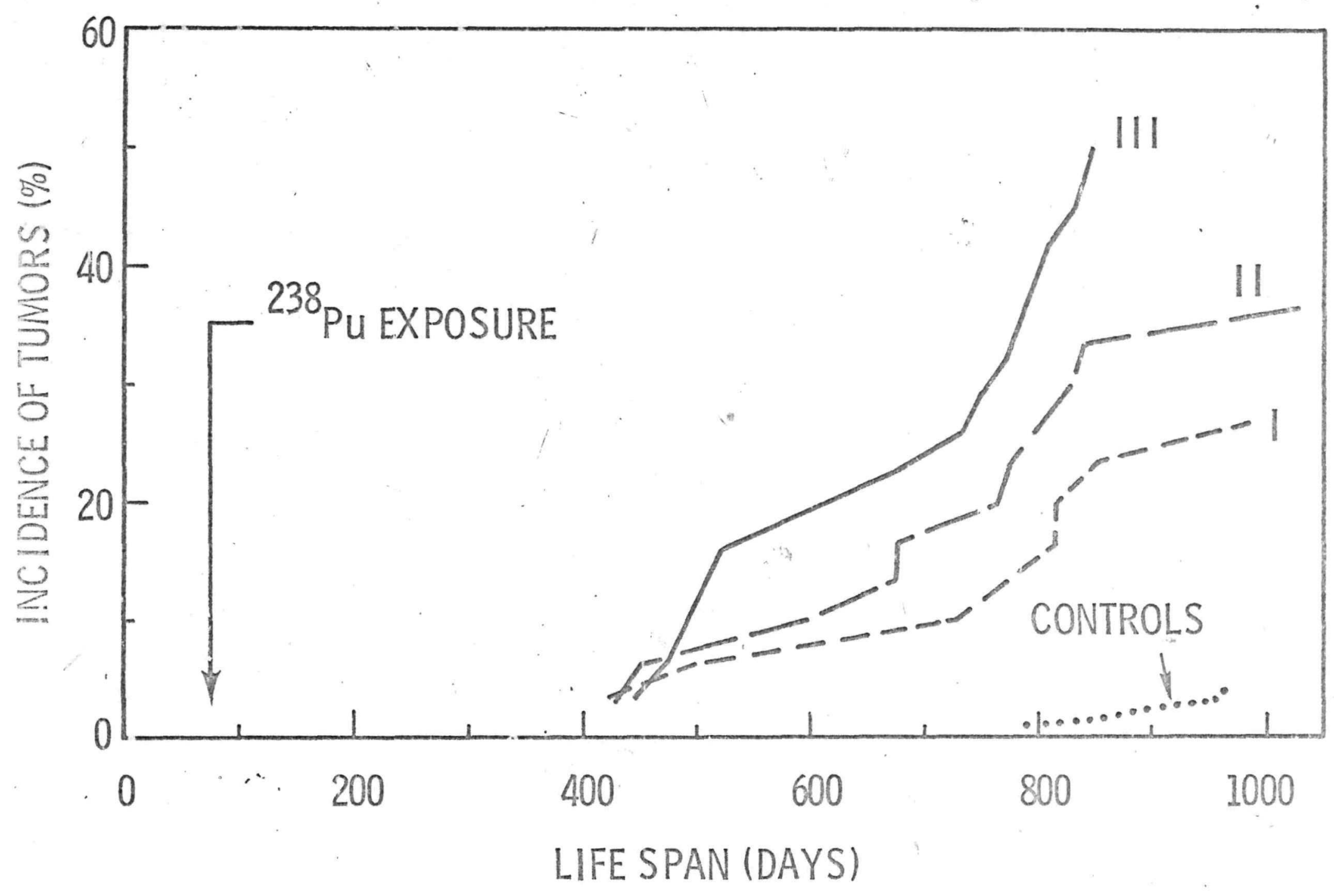




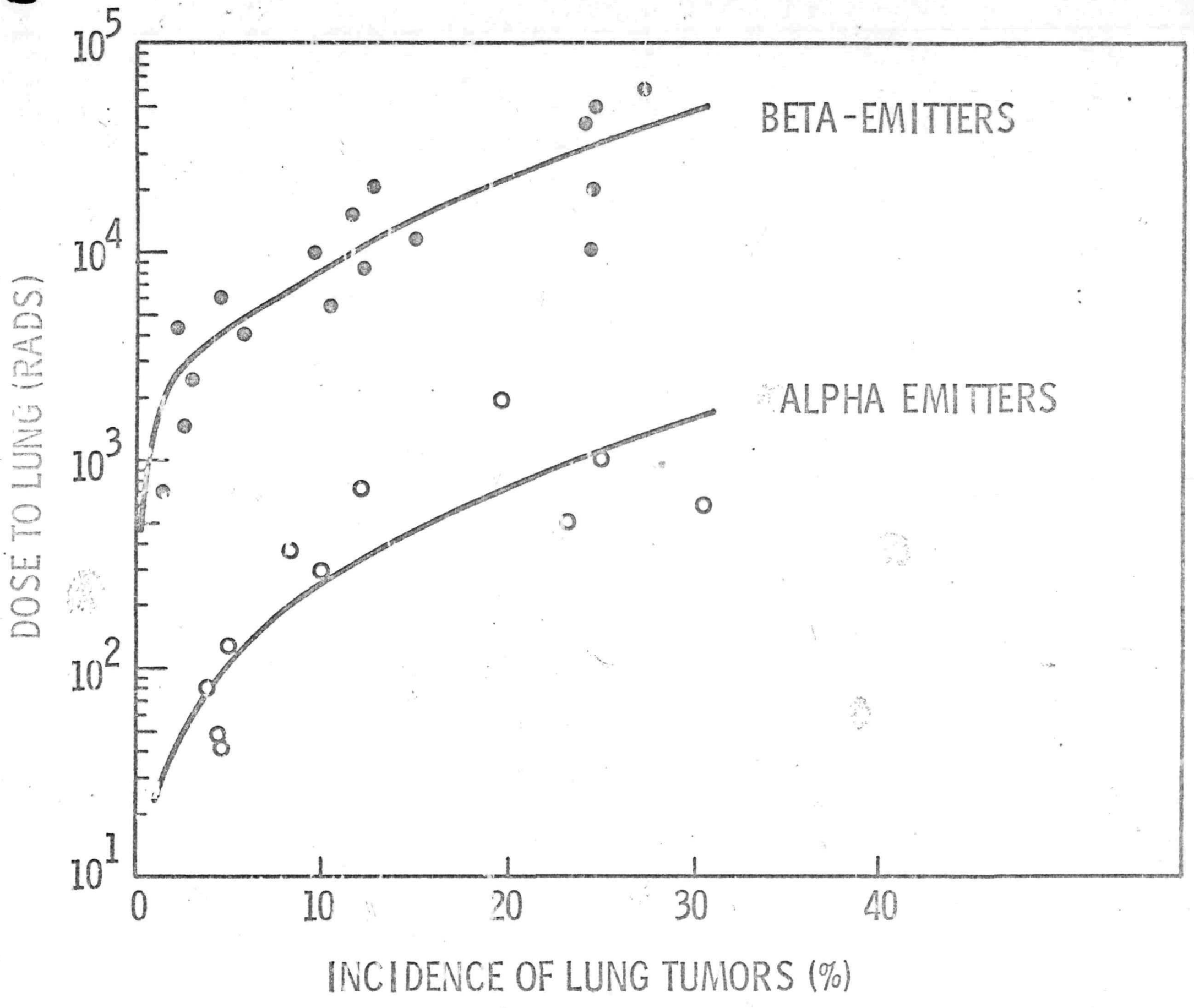

